\title{
Znaczenie warunków geomorfologicznych dla powstania i współczesnego stanu wybranych torfowisk w środkowym odcinku doliny Widawki
}

\author{
Importance of geomorphological features for origin and the contemporary situation of \\ selected peatlands in the middle Widawka river valley
}

\section{Emilia Stępień, Jacek Forysiak*}

*Katedra Geomorfologii i Paleogeografii, Wydział Nauk Geograficznych, Uniwersytet Łódzki; jacekfor@interia.eu

\begin{abstract}
Zarys treści: Wśród form geomorfologicznych Kotliny Szczercowskiej znaczną powierzchnię stanowią równiny torfowe. $\mathrm{W}$ artykule przedstawione są trzy przykłady torfowisk, dwa z nich powstały w paleomeandrach Widawki, położonych w obrębie dna dolinnego, trzecie leży w obniżeniu na terasie nadzalewowej, otoczonym piaskami eolicznymi. Rozpoznana została miąższość utworów biogenicznych, a w wybranych profilach wykonano oznaczenia parametrów fizykochemicznych i wydatowano spągowe warstwy torfów. Akumulacja torfów rozpoczęła się w późnym vistulianie i trwała w holocenie. W torfowiskach położonych $\mathrm{w}$ dnie doliny odłożyły się głównie torfy niskie, zaś w torfowisku położonym w otoczeniu form eolicznych torfy przejściowe i wysoki. Położenie geomorfologiczne znajduje również odbicie we współczesnym stanie torfowisk, które leżą w brzeżnej części leja depresji powstałego w otoczeniu odkrywki węgla brunatnego.
\end{abstract}

Słowa kluczowe: dolina rzeczna, paleomeander, torfowisko, dolina Widawki, środkowa Polska

Abstract: In Szczerców Basin peatlands have a significant participation among geomorphological forms. The article presents three examples of peatlands, two of them are formed in palaeochannel of Wiawka river, in valley floor, third one is located in small depression in high terrace, surrounded by aeolian sands. Thickness of biogenic deposits were examined and in selected cores were measured basic physico-chemical parameters. The bottom of peat layers was dated of radiocarbon method. Accumulation of peat series was started in Late Vistulian and gone in Holocene. In peatlands located in valley floor peat was deposited in fens, in high terrace it was transitional and raised peatland. Geomorphological features are important for the modern situation of peatlands, because they lie in the marginal part of the depression of ground water table, caused by the opencast mine of brown coal.

Key words: river valley, palaeochannel, peatland, Widawka river valley, Central Poland

\section{Wprowadzenie}

Dolina Widawki jest osią hydrograficzną Kotliny Szczercowskiej. Kształtowanie doliny było silnie związane $z$ przebiegiem procesów glacjalnych w okresie stadiału warty oraz procesów postglacjalnych, formujących późnoczwartorzędowe serie osadów, jak też obecną morfologię powierzchni kotliny. Kotlina Szczercowska jest przykładem obszaru o wysokim odsetku torfowisk we współczesnej powierzchni (Mamiński 1986, Kucharski, Pisarek 2001, Okupny i in. 2014), także znacznego zróżni- cowania pochodzenia mis torfowisk, jak też wie$\mathrm{ku}$ rozpoczęcia akumulacji osadów biogenicznych (Forysiak 2012). Analiza rozmieszczenia torfowisk w regionie lódzkim, bazująca na danych z połowy XX wieku (Okupny i in. 2014), pozwoliła stwierdzić, że w okolicach Bełchatowa i Szczercowa ilość złóż torfu wynosi 16 na $100 \mathrm{~km}^{2}$, co jest jedną z najwyższych wartości w strefie nizin staroglacjalnych, obok Polesia Lubelskiego i Równiny Łukowskiej (Żurek 1987). Lokalizacja odkrywek kopalni węgla brunatnego w obrębie Kotliny Szczercowskiej i przyległej do niej Wysoczyzny Bełchatowskiej spowodowała 
całkowite usunięcie wielu torfowisk, położonych w obrębie terenu przeznaczonego do eksploatacji, jak też w strefach zwałowisk. Znacznie większa ilościowo i powierzchniowo reprezentacja torfowisk poddana została degradacji w wyniku oddziaływania leja depresji, powstałego w wyniku obniżenia poziomów wód gruntowych obszaru (Maksymiuk 1985, Jokiel, Maksymiuk 1988). Na torfowiskach w latach osiemdziesiątych XX wieku zatrzymany został proces torfotwórczy i zapoczątkowana decesja pokrywy torfowej; w wyniku przesuszenia powierzchniowej warstwy torfu rozpoczęło się intensywne jego murszenie i mineralizacja (m.in. Gawlik 1994), postępujące $z$ czasem $w$ głąb profilu.

Procesy degradacji torfowisk, a zwłaszcza ich postęp i stan zachowania pokrywy torfu w obiektach poddanych oddziaływaniu leja depresji, są uzależnione od położenia geomorfologicznego torfowisk. Koryto Widawki poniżej obszaru eksploatacji stanowi drogę odpływu wód z systemu odwodnienia kopalni, co powoduje że w tej części doliny, pomimo obecności leja depresji w poziomach wód gruntowych, sytuacja wilgotnościowa w obszarze dna doliny i częściowo terasy niskiej Widawki jest stosunkowo dobra. Do analizy wybrano trzy torfowiska, dwa z nich leżą w obrębie dna doliny Widawki, współczesne oddziaływanie leja depresji Kopalni Węgla Brunatnego "Bełchatów" jest tam niewielkie (torfowiska: Trząs i Kawalce-Widawka), trzeci obiekt (torfowisko Kawalce-Las) położony jest na terasie nadzalewowej i jest ono objęte oddziaływaniem długotrwałego odwodnienia. Uzyskane dotychczas wyniki badań pozwalają na rozważanie wpływu geomorfologicznych cech mis analizowanych torfowisk na powstanie torfowisk, jak też na ich współczesną degradację, natomiast są jeszcze zbyt ograniczone dla rozważań stratygraficznych i rekonstrukcji rozwoju torfowisk.

\section{Położenie obszaru badań}

Teren badań położony jest w środkowej Polsce, w dolinie Widawki, w jej środkowym odcinku, który w regionalizacji fizycznogeograficznej wg Kondrackiego (2009) należy do Kotliny Szczercowskiej. Podobnie obszar ten określony jest $\mathrm{w}$ podziale na jednostki geomorfologiczne Gilewskiej (1999). Torfowiska objęte badaniami zlokalizowane są około $6 \mathrm{~km}$ na północ od odkrywki Kleszczów Kopalni Węgla Brunatnego „Bełchatów”, zaś w stosunku do koryta Widawki leżą kilkaset metrów na południe (ryc. 1). Wspomniany we wprowadzeniu zasięg leja depresji jest zmienny, w latach 80. sięgał bezpośrednio do koryta Widawki na analizowanym odcinku (Maksymiuk 1985), $\mathrm{w}$ dalszych latach granica jego oddziaływania prezentowana w dokumentach KWB Bełchatów na ogół

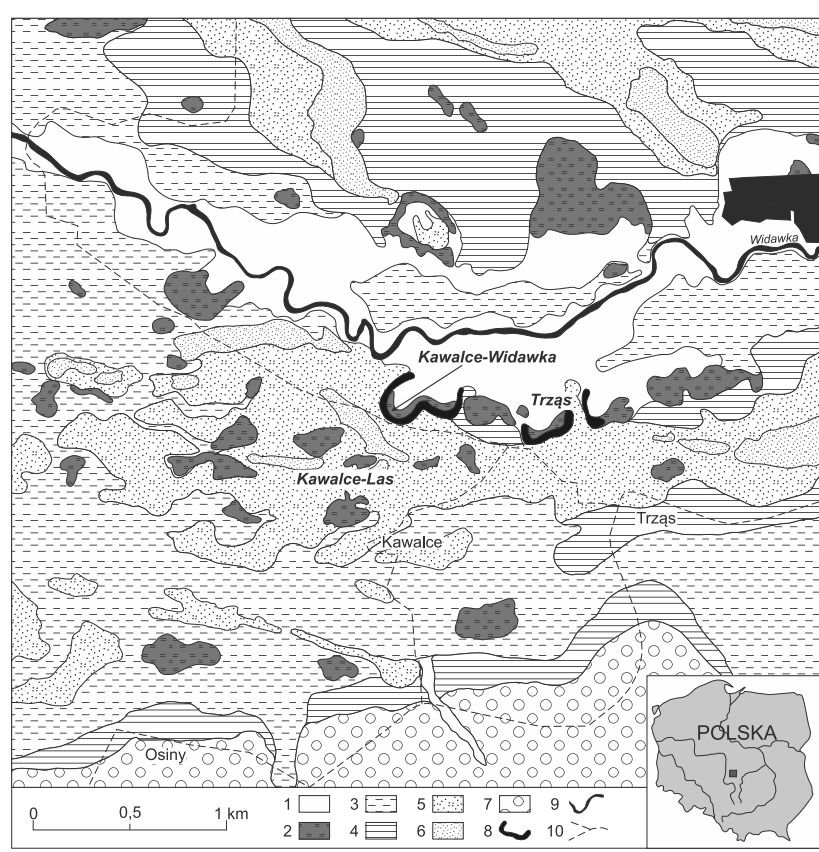

Ryc. 1. Szkic geomorfologiczny fragmentu środkowego odcinka doliny Widawki

1 - dna dolin, 2 - torfowiska, 3 - terasa niska, 4 - terasa wysoka, 5 - pola piasków eolicznych, 6 - wydmy, 7 - równina wodnolodowcowa, 8 - starorzecza, 9 - wody powierzchniowe, 10 - drogi

Fig. 1. Geomorphological map of the middle part of the Widawka river valley

1 - valley floor, 2 - peatlands, 3 - low terrace, 4 - high terrace, 5 - aeolian plains, 6 - dunes, 7 - fluvioglacial plain, 8 - palaeochannels, 9 - waters, 10 - roads

przebiega wzdłuż krawędzi dna doliny, lub północnego skraju terasy nadzalewowej. Badane obiekty są niewielkimi torfowiskami: torfowisko Trząs ma powierzchnię około 2 ha, torfowisko określone jako Kawalce-Widawka zajmuje 1,8 ha, natomiast Kawalce-Las około 1,4 ha. Torfowisko Trząs znajduje się około 500 m na północny zachód od zabudowań wsi o tej samej nazwie. W odległości około $300 \mathrm{~m}$ na zachód od niego leży torfowisko Kawalce-Widawka (ryc. 1). Obydwa obiekty znajdują się w obrębie dna doliny Widawki. Torfowisko Kawalce-Las położone jest około $800 \mathrm{~m}$ na południowy zachód w stosunku do wyżej wymienionych torfowisk, leży na obszarze wyższego poziomu terasowego doliny Widawki, który przykryty jest cienką pokrywą piasków eolicznych.

\section{Metody badań}

Prace badawcze przebiegały $\mathrm{w}$ kilku etapach. We wstępnej fazie badań przeprowadzono analizę map topograficznych i zdjęć lotniczych, które pozwoliły na wytypowanie obiektów badawczych. Prace terenowe podjęto w lecie 2014 roku i wykonano:

- wyznaczenie zasięgu torfowisk, określając przebieg granicy osadów torfowych i występowania 
roślinności torfotwórczej, z lokalizacją przy pomocy odbiornika GPS;

- sondowania geologiczne przy użyciu laski holenderskiej, co dało możliwość rozpoznania miąższości osadów biogenicznych oraz wytypowania miejsc poboru rdzeni do badań laboratoryjnych; sondowania były również przydatne do określenia cech makroskopowych osadów i wykonania trzech przekrojów;

- określanie cech makroskopowych osadów: miąższości warstw, barwy, stopnia rozkładu, granicy między warstwami oraz rodzaju osadów biogenicznych (Tobolski 2000);

- pobór rdzeni osadów przy użyciu próbnika torfowego Instorf, o średnicy $50 \mathrm{~mm}$ i $500 \mathrm{~mm}$ długości puszki. W miejscach o największej stwierdzonej miąższości pobrano rdzenie $\mathrm{w}$ dwóch stanowiskach: Trząs (oznaczony TE) i Kawalce-Las (oznaczony KE). Z torfowiska Kawalce-Widawka nie pobrano osadów $z$ powodu ogólnej małej ich miąższości i zaawansowanego stopnia rozkładu torfu.

Prace laboratoryjne przeprowadzono laboratorium Katedry Geomorfologii i Paleogeografii Uniwersytetu Łódzkiego. W warunkach laboratoryjnych rdzenie osadów zostały opróbowane ze standardową rozdzielczością $5 \mathrm{~cm}$. W ten sposób do dalszych prac laboratoryjnych przygotowano 41 próbek $z$ torfowiska Kawalce-Las i 49 próbek z torfowiska Trząs. Badania te miały na celu oznaczenie podstawowych parametrów fizykochemicznych i obejmowały:

- oznaczenia $\mathrm{pH}$, potencjału redoks oraz konduktywności wykonane zostały metodą elektrometryczną;

- oznaczenia popielności - próbki materiału poddano prażeniu w temperaturze $550^{\circ} \mathrm{C}$;

- oznaczenia wilgotności, zgodnie $z$ postępowaniem zaproponowanym przez Myślińską (2006).

Pobrane zostały także próbki torfu w celu oznaczenia wieku osadu metodą radiowęglową, wykonane metodą konwencjonalną $\mathrm{w}$ Laboratorium Datowań Bezwzględnych w Skale (MKL).

\section{Warunki geomorfologiczne i geologiczne obszaru badań}

Główne rysy rzeźby Kotliny Szczercowskiej zostały ukształtowane w schyłkowym okresie zlodowacenia odry - w stadiale warty, podczas aktywnego oddziaływania lądolodu, a następnie deglacjacji obszaru, jak też formowania się systemu odpływu wód proglacjalnych. W peryferycznych częściach kotliny oraz w obrębie przylegającej od wschodu Wysoczyzny Bełchatowskiej uformowane zostały pagórki kemowe, zaś w środkowej części powstało obniżenie, będące pozostałością po wytopieniu licznych brył martwego lodu (Turkowska 2006).

Osiowa część Kotliny Szczercowskiej, z doliną Widawki kształtowała się podczas całego okresu vistulianu, postglacjalne obniżenia wypełniane były osadami rzecznymi i stokowymi (m.in. Goździk, Zieliński 1996, Manikowska 1996), zwłaszcza w plenivistulanie. Końcowym efektem plenivistuliańskiej aktywności procesów rzecznych są rozległe terasy nadzalewowe, wyraźnie zaznaczone we współczesnej rzeźbie badanego terenu (ryc. 1). Baraniecka i Sarnacka (1971) wyróżniły w środkowym odcinku doliny Widawki dwie terasy nadzalewowe wyższą i niższą. Poziom wyższy położony jest około 8-10 m nad poziom rzeki (Gawlik 1970) i nadbudowany licznymi formami eolicznymi (Gawlik 1970, Wieczorek, Stoiński 2013). Struktura i osady tworzące wypełnienie doliny Widawki najlepiej rozpoznane zostały w strefie odkrywki kopalni Bełchatów (m.in.: Baraniecka 1987, Brodzikowski i in. 1987, Goździk, Zieliński 1996). Na obszarze badań ten poziom terasowy występuje $\mathrm{w}$ postaci płatów (ryc. 1), a jego rzędne osiągają wartości od 175 m n.p.m. do 177 m n.p.m. Drugi, niższy poziom nadzalewowy w dolinie Widawki, powstał $\mathrm{w}$ późnym vistulianie i korelowany jest $z$ niską terasą nadzalewową (Turkowska 2006), która przez Gawlika (1970) określona została jako terasa powodziowa. Terasa ta w środkowym odcinku doliny Widawki leży od 2 do $4 \mathrm{~m}$ ponad poziomem rzeki. W sąsiedztwie badanych torfowisk dominuje ona w obrazie geomorfologicznym doliny, jej powierzchna leży na wysokości od około 170 do 175 m n.p.m. W obrębie terasy niskiej występują formy eoliczne, zaś $\mathrm{w}$ obniżeniach niewielkie izolowane torfowiska.

Z okresem późnego vistulianu w Kotlinie Szczercowskiej, także w opisywanym odcinku doliny Widawki, wiązane są aktywne procesy eoliczne, głównie akumulacyjne, co dokumentują formy wydm oraz pola piasków eolicznych. Procesy te przebiegały podobnie jak w całej środkowej Polsce, wg schematu zaproponowanego przez Dylikową (1967), jako etapy tworzenia form eolicznych, przedzielane fazami rozwoju pokrywy glebowej. Sekwencja ta rozpoczęła się najstarszym dryasie, w starszym dryasie nastąpiła faza wydmotwórcza właściwa, zaś przemodelowanie części wydm nastąpiło w młodszym dryasie. Fazy te rozdzielone były ociepleniami (bølling i alleröd), kiedy dochodziło do rozwoju pokrywy glebowej, co zatrzymywało rozwój form piaszczystych. Na obszarze Kotliny Szczercowskiej nie zanotowano zdaniem Gawlika (1969, 1970) pierwszej, wstępnej fazy, ponieważ teren był silnie uwilgotniony, co hamowało procesy eoliczne. W obrębie badanego obszaru występują duże formy wydmowe, zwłaszcza po północnej stronie doliny (ryc. 1), ich rzędne dochodzą do 190 m n.p.m. W południowej części znacznych roz- 
miarów wydma znajduje się w miejscowości Trząs, dorównująca rzędnymi wspomnianym wyżej. Bezpośrednio do opisywanych torfowisk przylegają płaty piasków eolicznych, z mniejszymi wydmami, jak forma w miejscowości Kawalce, osiągająca 180 m n.p.m.

Holoceńskie dno doliny Widawki na badanym odcinku ma zmienną szerokość (ryc. 1). Jego rzędna w miejscowości Trząs wynosi 173,3 m n.p.m. i opada w kierunku zachodnim do rzędnej 169,5 m n.p.m. (w miejscowości Żar). Współczesne koryto Widawki w jej środkowym biegu jest przekształcone w znacznym stopniu, co wynika z długoletnich prac hydrotechnicznych, ale przede wszystkim z powodu prowadzonych od czterdziestu lat prac górniczych. Poza skanalizowanymi odcinkami koryta, pojawiły się także liczne zbiorniki wodne. W rejonie miejscowości Trząs oraz dalej na zachód koryto ma układ kręty, z kilkoma wyraźnymi meandrami, gdzie aktywne jest podcinanie wypukłych brzegów. W obrębie dna doliny zaznaczają się starorzecza, wiele $z$ nich ma postać paleomeandrów, przylegających do krawędzi teras nadzalewowych, niektóre zostały zajęte przez torfowiska (ryc. 1).

\section{Cechy morfologiczne i litologiczne badanych torfowisk}

Torfowisko Trząs leży w peryferycznej strefie dna doliny, zajmuje ciąg starorzeczy o kształcie paleomeandrów, wraz z obszarem wewnątrz ich łuków. Paleokoryta te podcinają fragment wysokiego poziomu terasowego, przykrytego pokrywą piasków eolicznych. $\mathrm{Z}$ rozpoznania złoża osadów biogenicznych torfowiska Trząs wynika, że największe ich miąższości znajdują się właśnie u podnóża krawędzi terasy, gdzie wynoszą około $2 \mathrm{~m}$, a maksymalna miąższość to $2,6 \mathrm{~m}$ (ryc. 2). Pokrywa torfowa poza paleokorytem jest znacznie cieńsza, nie przekracza $0,5 \mathrm{~m}$. We wschodniej części torfowiska Trząs sondowanie osadów biogenicznych nie zostało wykonane z powodu występującego tam zbiornika wodnego. Przeważająca część powierzchni torfowiska nosi ślady eksploatacji torfu, a w strefie dużych miąższości torfu znajdują się liczne potorfowe zbiorniki, wypełnione wodą.

Osady biogeniczne to niemal wyłącznie torfy, jedynie w osi starorzecza w kilku sondowaniach

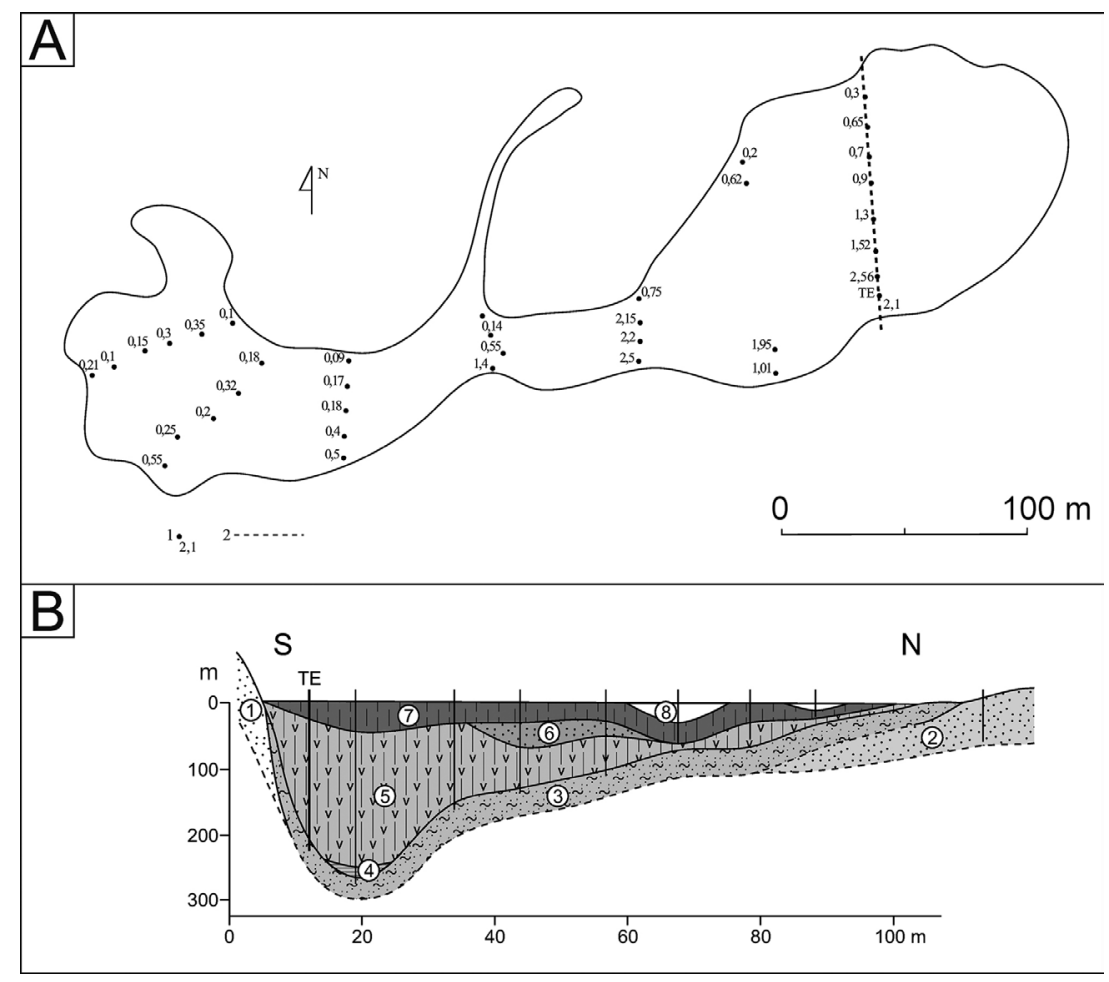

Ryc. 2. Torfowisko Trząs

A. Lokalizacja sondowań z wartościami miąższości osadów biogenicznych: 1 - punkty sondowań osadów biogenicznych, 2 - linia przekroju

B. Przekrój geologiczny: 1 - piaski rzeczne bez szczątków organicznych, 2 - piaski rzeczne ze szczątkami organicznymi, 3 - piaski różnoziarniste $z$ domieszką mułków organicznych, 4 - gytia detrytusowa, 5 - torf mszysto-zielny, 6 - torf z drewnem, 7 - torf silnie rozłożony z murszem, 8 - woda

Fig. 2. Trząs peatland

A. Location of drillings with thickness volume of biogenic deposits: 1 - drilling location, 2 - cross-section line

B. Geological cross-section: 1 - fluvial sand, without organic detritus, 2 - fluvial sand, with organic detritus, 3 - vari-grained sand with organic mud, 4 - detritus gyttja, 5 - peat (moss-herbaceous), 6 - peat with wood, 7 - peat with muck, 8 - water body 


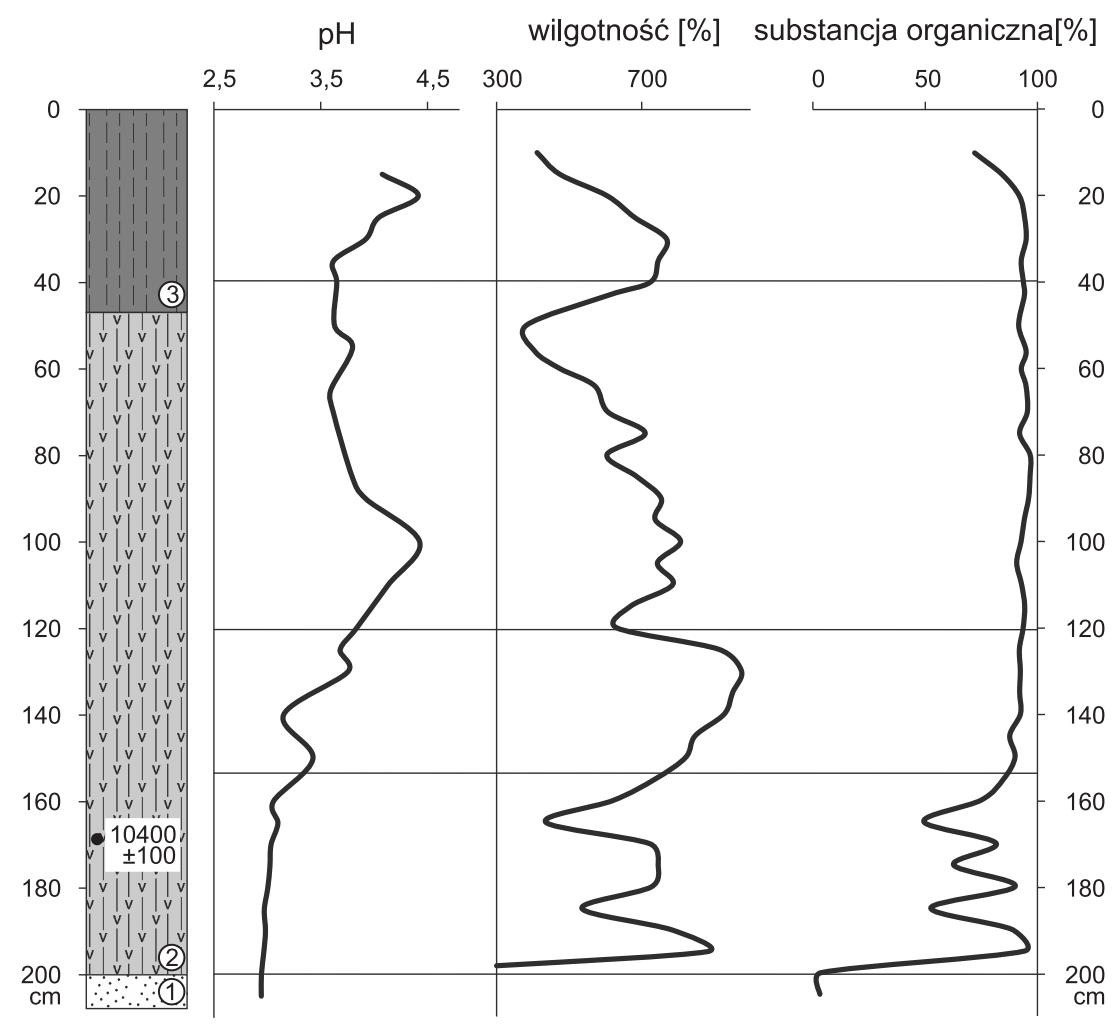

Ryc. 3. Wyniki oznaczeń parametrów fizykochemicznych profilu TE w torfowisku Trząs

1 - piasek drobnoziarnisty, 2 - torf mszysto-zielny, 3 - torf silnie rozłożony z murszem

Fig. 3. Basic physico-chemical parameters of the TE core deposits in Trząs peatland

1 - fine sand, 2 - peat (moss-herbaceous), 3 - decomposed peat with muck

stwierdzono cienką, kilkucentymetrową warstwę gytii grubodetrytusowej. Stropowa warstwa torfów jest w części torfowiska silniej rozłożona, jej miąższość wynosi od około 30 do $50 \mathrm{~cm}$. Podłoże serii biogenicznej stanowią średnio- i drobnoziarniste piaski, z udziałem rozdrobnionej substancji organicznej, które złożone zostały w końcowej fazie aktywności koryta. Z opisywanego starorzecza pobrano rdzeń TE, przeznaczony do analiz laboratoryjnych. Profil TE pobrany został $\mathrm{w}$ sąsiedztwie południowego brzegu torfowiska Trząs, tuż przy krawędzi paleokoryta. Ze względu na utrudnienia $\mathrm{w}$ przebiciu się przez przypowierzchniową warstwę korzeni, pobrano go w odległości kilku metrów na południowy zachód od miejsca o największej, stwierdzonej miąższości osadów biogenicznych.

Analiza cech litologicznych osadów oraz wartości oznaczonych parametrów fizykochemicznych dla rdzenia TE pozwoliły na wyznaczenie 5 stref (Materac 2015). Pierwszą strefę podłoża osadów biogenicznych stanowi piasek drobnoziarnisty z rdzawymi przewarstwieniami, który zalega poniżej głębokości $200 \mathrm{~cm}$ (ryc. 3). Do analiz pobrano z niego jedną próbkę tych osadów. Odczyn piasku jest silnie kwaśny, zaś udział części organicznych jest mniejszy niż jeden procent. Druga strefa to torf, zalegający na głębokości od 200 do $155 \mathrm{~cm}$, zawiera fragmenty drewna, domieszki drobnego piasku oraz cechuje się dość wysokim stop- niem rozkładu (około 60\%). Wartości odczynu są bardzo niskie, oscylują około wartości 3. Wilgotność torfu jest zróżnicowana $\mathrm{w}$ profilu głębokościowym złoża, tuż ponad piaszczystym podłożem przyjmuje wartość $870 \%$, następnie spada i po ponownym zwiększeniu maleje do około 430\%. Również zmienna jest $\mathrm{w}$ tej warstwie zawartość materii organicznej, w dolnej części złoża początkowo przyjmuje bardzo wysoki wynik, niemal 96\%, a w górę rdzenia waha się opadając do około $49 \%$ (ryc. 3). Z badanego rdzenia, z głębokości od 168 do $173 \mathrm{~cm}$ pobrano próbę do analizy wieku metodą radiowęglową, jej wynik to: $10400 \pm 100$ (MKL-2480), co pozwala powstanie tej warstwy torfu wiązać z młodszym dryasem. Trzecią strefę wyznaczono na głębokości od 155 do $120 \mathrm{~cm}$ profilu TE, stanowi ją torf średnio rozłożony (około $50 \%)$. Wartość odczynu w tej strefie wykazuje wahania przy jednoczesnej tendencji wzrostowej w górę profilu (od 3,43 do 3,83). Wilgotność od głębokości 155 do $130 \mathrm{~cm}$ cechuje się tendencją wzrostową (od 821 do 912\%) natomiast od 130 do $120 \mathrm{~cm}$ maleje do $669,2 \%$. Zawartość materii organicznej w dolnej części wynosi 90,8\%, wyżej spada nieznacznie i w górnej części profilu stabilizuje się na poziomie około $93 \%$. Czwarta strefa znajduje się między $120 \mathrm{~cm}$ i $40 \mathrm{~cm}$ badanego profilu, występuje tutaj torf zielny $z$ udziałem fragmentów drewna, charakteryzujący się nieco wyższym stopniem rozkładu. W dolnej części 


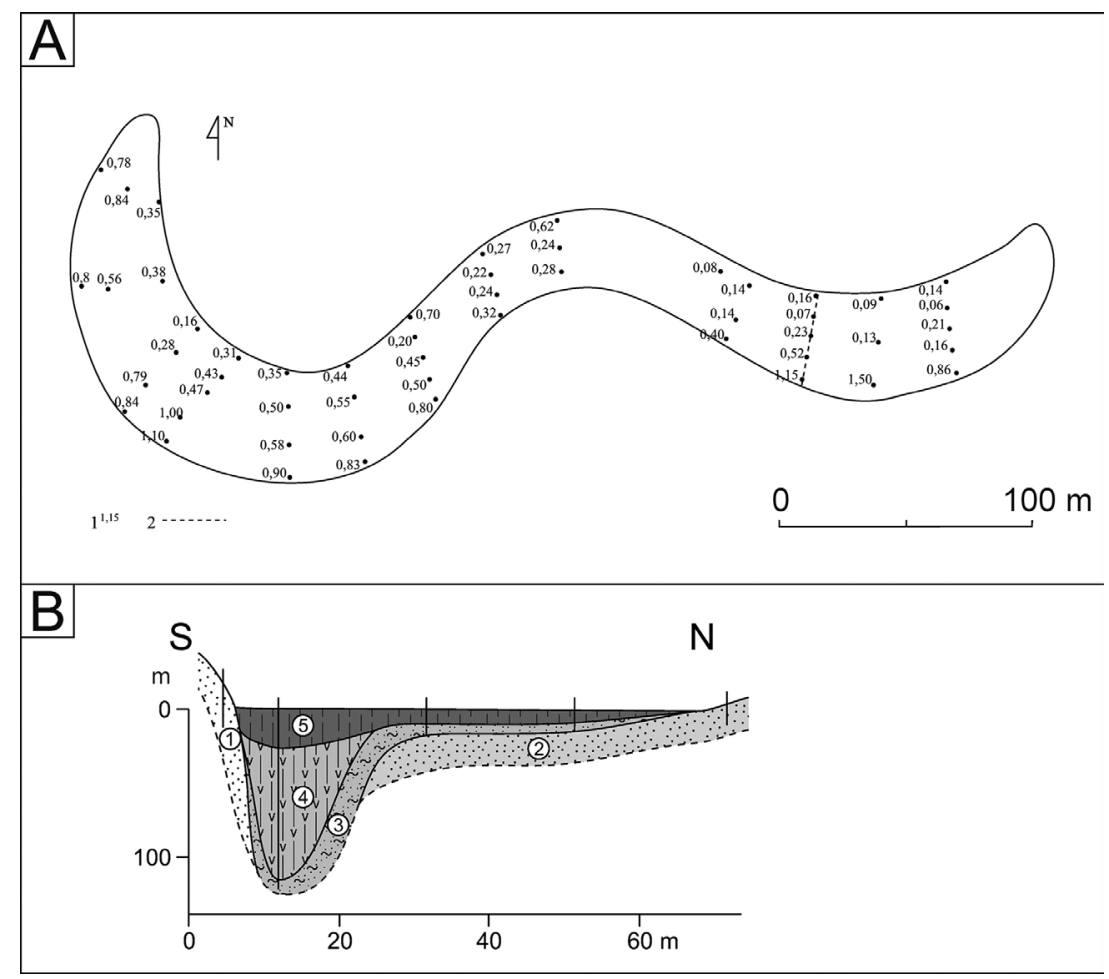

Ryc. 4. Torfowisko Kawalce-Widawka

A. Lokalizacja sondowań z wartościami miąższości osadów biogenicznych 1 - punkty sondowań osadów biogenicznych, 2 - linia przekroju

B. Przekrój geologiczny: 1 - piaski rzeczne bez szczątków organicznych, 2 - piaski rzeczne ze szczątkami organicznymi, 3 - piaski różnoziarniste z domieszkami mułków organicznych, 4 - torf mszysto-zielny, 5 - torf silnie rozłożony

Fig. 4. Kawalce-Widawka peatland

A. Location of drillings with thickness volume of biogenic deposits: 1 - drilling location, 2 - cross-section line

B. Geological cross-section: 1 - fluvial sand, without organic detritus, 2 - fluvial sand, with organic detritus, 3 - vari-grained sand with organic mud, 4 - peat (moss-herbaceous), 5 - decomposed peat

tej strefy odczyn torfu wzrasta do 4,43 a wyżej maleje do 3,65. Wskaźnik wilgotności także wyższy jest w dolnej części, gdzie po początkowym spadku osiąga wartości wahające się od około $610 \%$ do $785 \%$. $\mathrm{W}$ górnej części znacznie spada. Zawartość materii organicznej jest bardzo wysoka i zmienia się w niewielkim zakresie między 91,6 do $98 \%$. Piąta strefa to przypowierzchniowa warstwa silnie rozłożonego torfu i murszu. W dolnej części, na głębokości 40 $\mathrm{cm}$ jego odczyn wynosi 3,62, natomiast w górę profilu wzrasta do 4,41. Wilgotność osadu po osiągnięciu wysokiej wartości na głębokości $35 \mathrm{~cm}$ (768\%), maleje ku powierzchni (ryc. 3). Podobnie zawartość materii organicznej początkowo jest wysoka, ale ku powierzchni maleje do około 74\%. Górną część tej strefy (około $10 \mathrm{~cm}$ ) stanowi warstwa świeżego torfu mszystego, z udziałem szczątków roślin zielnych.

Torfowisko Kawalce-Widawka. Położenie geomorfologiczne torfowiska Kawalce-Widawka jest podobne do torfowiska Trząs. Leży ono w obrębie dna doliny, bezpośrednio pod krawędzią terasy nadzalewowej, nadbudowanej piaskami eolicznymi. Przyjmuje kształt połączonych dwóch fragmentów meandro- wego koryta rzecznego, zatorfienie obejmuje również wewnętrzną część paleomeandrów. Największe miąższości torfu związane są z przegłębieniami w kopalnym korycie. W tym przypadku miąższość torfu jest znacznie mniejsza, maksymalne wartości występują $\mathrm{w}$ południowo-wschodniej części, osiągając $1,15 \mathrm{~m}$, jak również w południowo-zachodniej części $(1,1 \mathrm{~m})$, w pozostałych odcinkach torfowiska nie przekraczają $1 \mathrm{~m}$ (ryc. 4). Udokumentowana seria osadów biogenicznych składa się głównie z torfu mszysto-zielnego. Przypowierzchniowa warstwa silnie rozłożonego torfu jest cieńsza niż w przypadku torfowiska Trząs, a mursz występuje tylko w miejscach wyższego położenia powierzchni torfowiska.

Torfowisko Kawalce-Las położone jest w obrębie terasy niskiej Widawki, która nadbudowana jest w tym rejonie utworami eolicznymi. Misa torfowiska znajduje się $\mathrm{w}$ obniżeniu między niskimi pagórkami pola eolicznego (ryc. 1). Ma ona owalny kształt. Torfowisko jest silnie przekształcone przez prace eksploatacyjne, a współczesna powierzchnia jedynie w obrębie kilku niewyeksploatowanych grobli nawiązuje do naturalnej. W obrębie takiego właśnie wy- 


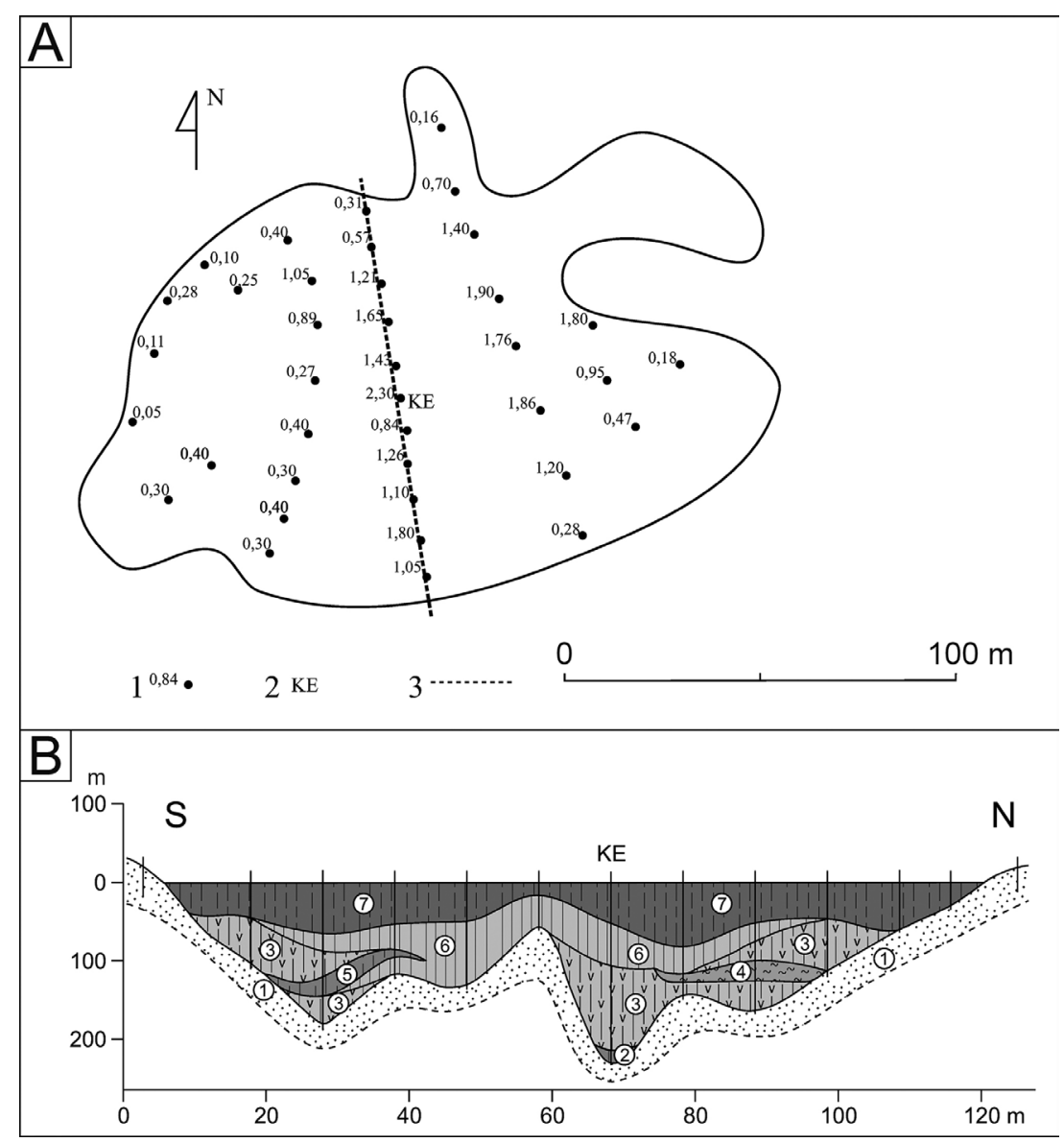

Ryc. 5. Torfowisko Kawalce-Las

A. Lokalizacja sondowań z wartościami miąższości osadów biogenicznych: 1 - punkty sondowań osadów biogenicznych, 2 - położenie profilu KE (ryc. 6), 3 - linia przekroju

B. Przekrój geologiczny: 1 - piaski drobno- i średnioziarniste, 2 - torf silnie rozłożony, 3 - torf mszysto-zielny, 4 - mułek organiczny, 5 - torf silnie rozłożony z murszem, 6 - torf zielny, 7 - torf silnie rozłożony i mursz

Fig. 5. Kawalce-Las peatland

A. Location of drillings with thickness volume of biogenic deposits: 1 - drilling location, 2 - location of KE core (Fig. 6), 3 - cross-section line

B. Geological cross-section: 1 - fine and medium-grained sand, 2 - decomposed peat, 3 - peat (moss-herbaceous), 4 - organic mud, 5 - decomposed peat with muck, 6 - herbaceous peat, 7 - peat with muck

niesienia, wydłużonego w kierunku północ-południe stwierdzono dwumetrową miąższość torfów (ryc. 5). Rdzeń osadów KE pobrano w środkowej części torfowiska, w miejscu o największej miąższości osadów biogenicznych.

Cechy litologiczne oraz parametry fizykochemiczne osadów w profilu KE pozwoliły na wyznaczenie 6 stref (Materac 2015). Pierwszą strefę tworzy piasek różnoziarnisty, który występuje na głębokości poniżej $198 \mathrm{~cm}$, stanowiąc podłoże osadów biogenicznych w badanym profilu. Pobrana z niego próbka wykazała kwaśny odczyn i bardzo wysoką popielność, nieco ponad $98 \%$ (ryc. 6). Druga ze stref została wyznaczona między 198 i $180 \mathrm{~cm}$ profilu. Jest to silnie rozłożony torf, częściowo z murszem, utwór na brunatno-czarną barwę, z kilkoma jaśniejszymi warstewkami. Odczyn osadu wynosi od 4,17 do 4,9 i osiąga najwyższe wartości w całym profilu. Zawartość materii orga- nicznej wzrasta w tym odcinku od 27,1 do $60,3 \%$. Wilgotność osadu także wykazuje wzrost od $323 \%$ do 493\%. Oznaczenie wieku osadu z głębokości 198-195 $\mathrm{cm}$ metodą radiowęglową dało wynik 11 970 \pm 110 (MKL-2481), co po kalibracji pozwala określać wiek na około 13800 lat BP (Walanus, Goslar 2009) i przyjąć początek akumulacji torfu na przełomie starszego dryasu i początku allerödu (Ralska-Jasiewiczowa i in. 1998, Dzieduszyńska, Forysiak 2015). Trzecią strefę wydzielono między głębokością 180 i $140 \mathrm{~cm}$ (ryc. 4). Występuje tutaj torf mszysto-zielny, słabo rozłożony. Jego odczyn jest silnie kwaśny, początkowo osiąga minimum wynoszące 3,7 , następnie wartości pH nieznacznie rosną do nieco powyżej 4,0. Wilgotność już w spągu tej warstwy silnie rośnie i osiąga wysokie wartości około $900 \%$. Zawartość materii organicznej początkowo jest podobna do osadów poniżej, ale od $170 \mathrm{~cm}$ wzrasta do niemal 95\% (ryc. 4). Następna, 


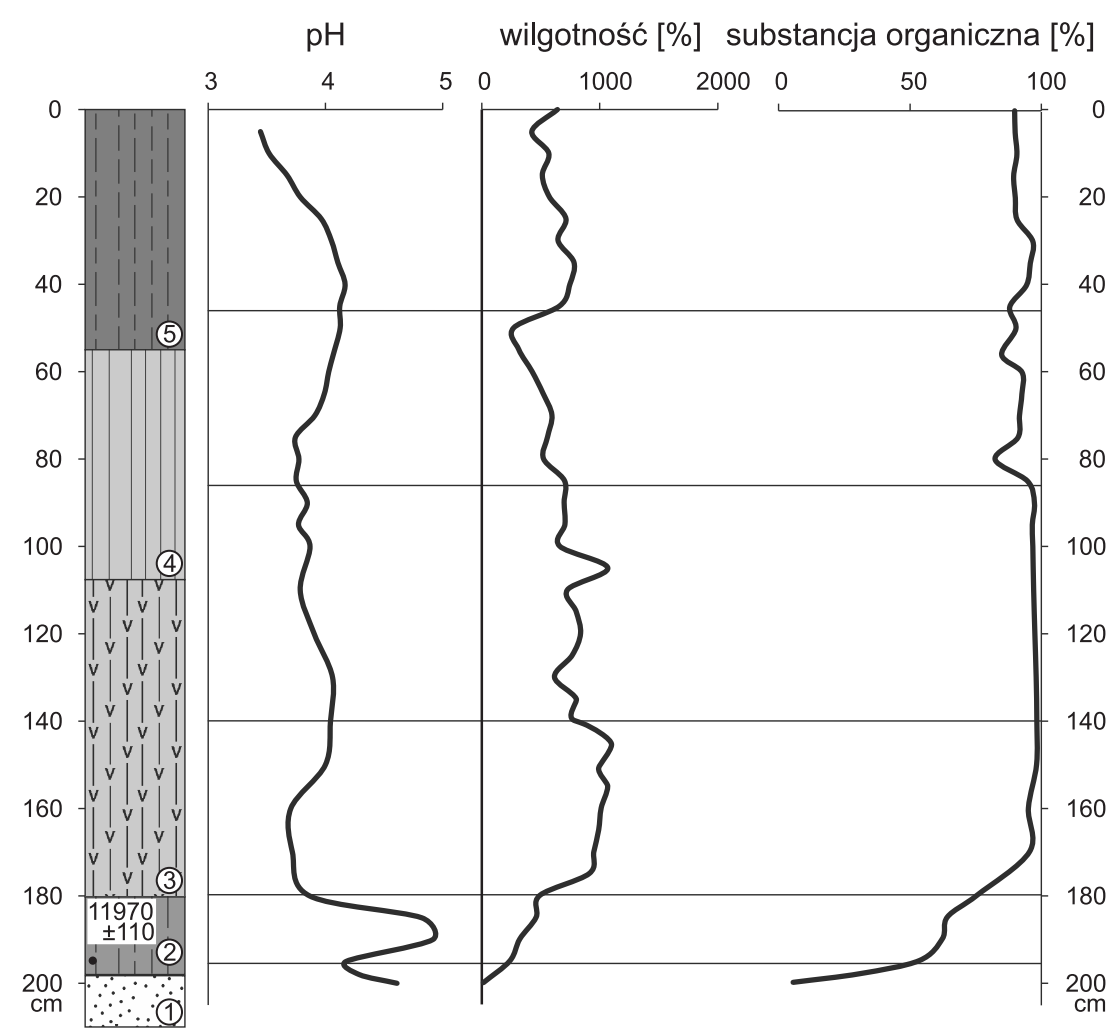

Ryc. 6. Wyniki oznaczeń parametrów fizykochemicznych profilu KE w torfowisku Kawalce-Las

1 - piasek drobnoziarnisty, 2 - torf silnie rozłożony, 3 - torf mszysto-zielny, 4 - torf zielny, 5 - torf silnie rozłożony z murszem.

Fig. 6. Basic physico-chemical parameters of the KE core deposits in Kawalce-Las peatland

1 - fine sand, 2 - decomposed peat, 3 - peat (moss-herbaceous), 4 - herbaceous peat, 5 - decomposed peat with muck

czwarta strefa znajduje się na głębokości od 140 do $85 \mathrm{~cm}$, stanowi ją torf zielno-mszysty, o słabym stopniu rozkładu. W tej warstwie zaznaczył się niewielki spadek wartości pH, (od 4,0 do 3,85). Wskaźnik wilgotności zawiera się między około 700 a $1000 \%$ i wykazuje zmienność $\mathrm{w}$ profilu. Zawartość substancji organicznej w całej strefie jest względnie stała i waha się około wartości $93 \%$. Kolejną strefę w przedziale głębokości od 85 do $45 \mathrm{~cm}$ wydzielono na podstawie wzrostu zmienności opisywanych parametrów fizykochemicznych. W dolnej części nadal jest to torf zielny z udziałem elementów mszystych, ale cechuje się już większym stopniem rozkładu. Odczyn wykazuje tendencję wzrostową (od 3,7 do 4,12), wskaźnik wilgotności jest generalnie niższy niż w osadach wcześniej opisanych, zaznaczają się w nim dwie warstwy ze znacznym spadkiem (ryc. 4). Również zawartość substancji organicznej, w tej strefie jest mniejsza, a w tych samych warstwach, gdzie notowane są spadki wilgotności osadu spada do około 78,5 i 81\%. Stropowa, szósta strefa ma miąższość $45 \mathrm{~cm}$, charakteryzuje się występowaniem czarnego murszu, wykazującego cechy całkowitego rozkładu masy torfowej. Jego odczyn spada od 4,1 do 3,4. Wilgotność waha się $\mathrm{w}$ dużym zakresie, od 425 do $781 \%$, zaś zawartość materii organicznej, początkowo bardzo wysoka, w przypowierzchniowej warstwie spada do około $85 \%$.

\section{Znaczenie cech geomorfologicznych dla powstania badanych torfowisk}

Większość torfowisk położonych w badanym odcinku doliny Widawki zostało silnie przekształcone w wyniku presji gospodarczej (odwodnienia, eksploatacja torfu) w XIX i XX wieku, co wyklucza możliwość prowadzenia analiz osadów biogenicznych. Przed przystąpieniem do badań terenowych dokonano więc selekcji obiektów, odrzucając te, których złoża zostały niemal $\mathrm{w}$ całości wyeksploatowane. Wiele $z$ nich zostało także silnie odwodnionych w związku z eksploatacją węgla brunatnego w odkrywce Kleszczów. W obrębie dna doliny, a także częściowo niskiego poziomu dolinnego występuje kilkanaście niewielkich pod względem powierzchni torfowisk, związanych z systemem starorzeczy, jednak na ogół miąższość wypełniających je torfów nie jest duża, co dobrze ilustruje przykład torfowiska Kawalce-Widawka. Większą miąższością cechuje się jedynie kilka obiektów, wśród nich torfowisko Trząs. Poza starorzeczami torfowiska zajmują także obniżenia o charakterze basenów powodziowych $\mathrm{w}$ dnie doliny. Liczne są także torfowiska położone między wydmami oraz w obrębie pól eolicznych, które pokrywają terasę niską. 
Dolina Widawki w opisywanej części jest rozległa, terasa wysoka na wschód od Szczercowa ma około 4 km szerokości. Terasa niska w okolicy Trząsu i Kawalców również jest rozległa, rozdzielona na dwie strefy przez fragment terasy wysokiej i kompleks form eolicznych. Terasa niska w dolinach rzecznych regionu łódzkiego jest, jak wcześniej wspomniano, wiekowo związana $z$ późnym vistulianem (por. Turkowska 1988, 2006). Po etapie erozji, na przełomie plenivistulianu i późnego vistulianu, została rozcięta i morfologicznie wyodrębniona terasa wysoka. Doszło do przekształcenia rzek roztokowych w jednokorytowe, meandrujące (m.in. Turkowska 1988, 2006, Forysiak 2005). Następnie zaznaczyły się $\mathrm{w}$ obrębie den dolin tendencje do agradacji osadów. W dnie ówczesnej doliny Widawki koryto rzeki meandrującej, przemieszczając się po równinie zalewowej podcinało krawędzie terasy wysokiej, a porzucane starorzecza stawały się miejscem akumulacji osadów powodziowych. W korzystnych sytuacjach, zwłaszcza podkrawędziowych, starorzecza nie były zapełniane osadami rzecznymi, ale dzięki dobremu zasilaniu wodami gruntowymi i opadowymi funkcjonowały jako zbiorniki wodne, a w dalszej kolejności następowało ich zatorfianie. Potwierdza to cienka warstwa gytii stwierdzona pod torfem w osi torfowiska Trząs. Spągową część profilu torfu o wysokim udziale substancji organicznej można wiązać $z$ fazą allerödu. Tworzenie się leżącego powyżej torfu, o zmiennych parametrach fizykochemicznych, zaliczonego do drugiej strefy, wiązać należy z młodszym dryasem, a znaczny udział substancji mineralnej wynikać może ze wzmożonej aktywności eolicznej w obrębie ówczesnego dna dolinnego. Kolejna strefę tworzy torf, który można określić jako przejściowy, o wysokiej wilgotności i małej zawartości domieszek mineralnych, Tworzył on się zapewne już w warunkach stabilnego zasilania ubogimi, płytkimi wodami gruntowymi i opadowymi we wczesnym holocenie, $\mathrm{w}$ warunkach stabilizacji procesów fluwialnych $\mathrm{w}$ dolinie oraz utrwalenia powierzchni teras przez roślinność, co zaznacza się także na innych torfowiskach dolinnych tego regionu (por. Forysiak 2012).

Powstanie misy torfowiska Kawalce-Las związane jest, jak już wspomniano, z procesami transportu i akumulacji piasków eolicznych oraz migracji niewielkich form eolicznych. Zdaniem Gawlika (1969) obniżenia, w których powstały torfowiska są efektem przemieszczania się tych form $\mathrm{w}$ starszym dryasie i odcinaniem obniżeń przez migrujące wydmy, jak i lokalnie przez silną deflację przesuszonego podłoża. Datowanie osadów ze spągu złoża torfów w profilu KE potwierdza taki pogląd. Jednak funkcjonujące wówczas siedlisko torfowiska niskiego narażone było ciągle na znaczną dostawę materiału mineralnego, zapewne z przyległych form eolicznych, słabo jeszcze pokrytych roślinnością. Prawdopodobnie okresowo zaznaczać się mógł deficyt wilgoci, co skutkowało dużym stopniem rozkładu torfu w tej warstwie. Można więc przyjąć, że w misie torfowiska Kawalce-Las sedentacja torfu zaczęła się na początku allerödu, być może bezpośrednio po okresie formowania się wcześniej wspomnianych obniżeń i pagórków wydmowych, podczas fazy wydmotwórczej starszego dryasu (Dylikowa 1967). Brak w analizowanym profilu KE warstwy wyraźnie wzbogaconej z substancję mineralną, którą można korelować z fazą młodszego dryasu. Zaznaczony w dolnej części trzeciej strefy (na głębokości około $170 \mathrm{~cm}$ ) znaczny wzrost wilgotności torfu mszysto-zielnego i silne zwiększenie zawartości materii organicznej, przy spadku odczynu, świadczy o rozwoju torfowiska przejściowego i wysokiego, funkcjonującego w korzystnych warunkach wilgotnościowych. Otaczający teren cechował się zapewne wówczas wysokim stopniem pokrycia przez roślinność. To pozwalałoby wiązać tę strefę z wczesnym holocenem. Pojawienie się fazy torfowiska wysokiego na obiektach towarzyszących formom eolicznym, na przykład torfowisku Rąbień, jest przez Klossa (2007) lokowane w środkowej części okresu atlantyckiego, ale w badanym torfowisku mogło nastąpić wcześniej, gdyż tutaj nie zaznaczył się etap jeziorny w rozwoju misy torfowiska. Kolejna wyraźna zmiana cech osadów rdzenia z torfowiska Kawalce-Las, jest zaznaczona przejściem ze strefy czwartej do piątej, już w obrębie warstwy torfu zielnego. Charakterystyczny jest znaczny spadek wilgotności torfu oraz skorelowany z nim spadek zawartości materii organicznej, co może wynikać zarówno z dostawy alochtonicznego materiału mineralnego, jak też ze zwiększonej mineralizacji osadu. Trudno jednak bez datowania osadu określić wiek tej warstwy. Jeśli wiązać ten stan $z$ rozluźnieniem szaty roślinnej $\mathrm{w}$ otoczeniu torfowiska, to jedynym czynnikiem jaki mógłby być przyczyną takiego stanu w holocenie jest działalność człowieka. Wówczas wiek powstania tej serii można wiązać $z$ neoholocenem, $z$ fazami antropogenicznymi, zaznaczającymi się $\mathrm{w}$ osadach deponowanych $\mathrm{w}$ różnych środowiskach sedymentacyjnych w regionie łódzkim (Twardy 2008).

Stropowe części serii torfowych w obu analizowanych torfowiskach zostały w znacznym stopniu zmienione $\mathrm{w}$ wyniku odwodnienia $\mathrm{w}$ drugiej połowie XX wieku i częściowej eksploatacji torfu, ale znacznie silniejszym impulsem było powstanie leja depresji wokół kopalni węgla brunatnego i długotrwałe obniżenie poziomu wody na torfowiskach. To doprowadziło do zmian wilgotności stropowych części profili torfowych, przez co ten wskaźnik stanu torfu nie może być brany pod uwagę przy interpretacji warunków akumulacji. Także silne przesuszenie i znacznie zaawansowany postęp murszenia oraz mineralizacji, które zwiększają relatywną zawartość materii mineralnej w torfie, ogranicza wykorzystanie także tego 
parametru. Torfowiska położone w obrębie dna doliny Widawki podlegały wpływom leja depresji tylko przy jego maksymalnym zasięgu (Materac 2015) i obecny stan roślinności torfotwórczej na torfowisku Trząs i Kawalce-Widawka jest zadowalający, a przypowierzchniową warstwę torfu $\mathrm{w}$ miejscu poboru analizowanego rdzenia stanowi słabo rozłożony torf mszysty $z$ fragmentami roślin zielnych. W przypad$\mathrm{ku}$ torfowiska Kawalce-Las sytuacja jest znacznie gorsza. Na torfowisku nie stwierdzono roślinności torfotwórczej, złoże jest silnie przesuszone i przypowierzchniowa warstwa wykazuje daleko posunięty etap murszenia i mineralizacji torfu. Stwierdzona sytuacja wskazuje na lepsze warunki dla przetrwania torfowisk i złóż torfu w warunkach długotrwałego oddziaływania odwodnienia terenu $\mathrm{w}$ starorzeczach $\mathrm{i}$ innych obniżeniach $\mathrm{w}$ obrębie dna doliny Widawki, niż w formach wklęsłych uformowanych przez procesy rzeczne i eoliczne na powierzchni terasy nadzalewowej.

\section{Podsumowanie}

Wybrane do analizy torfowiska stanowią przykłady licznych, niewielkich obiektów rozwijających się w Kotlinie Szczercowskiej od późnego vistulianu. Badane torfowiska pod względem cech geomorfologicznych obniżeń, w jakich powstały, są przykładami torfowisk dolinnych (por. Forysiak 2012). Torfowiska Trząs i Kawalce-Widawka są związane genetycznie $z$ obszarem dna aktywnej doliny rzecznej, natomiast Kawalce-Las z obniżeniem powstałym dzięki aktywnym procesom eolicznym. Takie położenie mis torfowisk wpływało na odmienne sposoby ich zasilania, obiekty położone $\mathrm{w}$ dnie doliny, $\mathrm{w}$ głębokich rozcięciach paleomeandrów, bezpośrednio przy krawędzi terasy nadzalewowej, funkcjonowały dzięki zasilaniu wodami fluwialnymi i gruntowymi, co ma odbicie w parametrach fizykochemicznych torfu. Torfowisko położone wyżej, w otoczeniu form eolicznych rozpoczęło funkcjonowanie dzięki stosunkowo wysokiemu poziomowi wód gruntowych, ale także dzięki wodom opadowym i ubogim w składniki mineralne wodom spływającym z niewielkiej zlewni bezpośredniej, co również jest czytelne w parametrach torfu.

Powstanie torfowisk $\mathrm{w}$ dnie doliny oraz na przyległej terasie nadzalewowej nastąpiło w zbliżonym czasie na przełomie starszego dryasu i allerödu, ale w torfowisku Trząs i Kawalce-Widawka akumulowany był głównie torf niski (zielny), zaś w torfowisku Kawalce-Las zarówno torf niski (w spągu), jak i torf przejściowy oraz wysoki. Ocena paleoekologicznej wartości analizowanych osadów mogłaby być większa, gdyby zostały wykonane analizy paleobotaniczne i geochronometryczne.
Warunki geomorfologiczne $\mathrm{w}$ jakich funkcjonowały badane torfowiska wpłynęły również na ich obecny stan. Obiekty położone w dnie doliny, w odległości kilkuset metrów od koryta Widawki, mimo położenia na skraju zasięgu leja depresji wód gruntowych, zachowują stosunkowo dobre warunki wilgotnościowe dzięki infiltracji wód $z$ koryta rzecznego i zapewne niewielkiego zasilania wodami gruntowymi wysączającymi się w obrębie krawędzi terasy. To pozwala na okresowe lub stałe funkcjonowanie zbiorowisk torfotwórczych. Torfowisko położone w obrębie terasy nadzalewowej i otoczone formami eolicznymi, w warunkach leja depresji podlega stałemu deficytowi wody, co doprowadziło do skrajnego przesuszenia powierzchniowej serii torfu i postępującego $\mathrm{w}$ głąb profilu procesu jego decesji i mineralizacji.

\section{Literatura}

Baraniecka M.D., 1987. Podstawy stratygrafii plejstocenu kopalni Bełchatów. W: Czwartorzęd rejonu Bełchatowa, II sympozjum Komitetu Badań Czwartorzędu Polskiej Akademii Nauk, Wrocław-Warszawa: 68-80.

Baraniecka M.D., Sarnacka Z., 1971. Stratygrafia czwartorzędu i paleogeografia dorzecza Widawki. W: Mojski J.E. (red.). Z badań czwartorzędu w Polsce. Biuletyn Państwowego Instytutu Geologicznego 13(254): 157-270.

Brodzikowski K., Krzyszkowski D., Van Loon A.J., 1987. Endogenic processes as a cause of penecontemporaneous soft - sediment deformations in the fluviolacustrine Czyżów Series (Kleszczów Graben, central Poland). W: M.E.Jones, R.M.F.Preston (eds), Deformation of Sediments and Sedimentary Rocks, Geological Society Special Publication 29: 269-278.

Dylikowa A., 1967. Wydmy środkowopolskie i ich znaczenie dla stratygrafii schyłkowego plejstocenu. W: R.Galon (red.), Czwartorzęd Polski. Wydawnictwo PWN, Warszawa: 353-371.

Dzieduszyńska D., Forysiak J., 2015. Late Glacial organic sediments in palaeogeographical reconstructions (cases from the Łódź region). Bulletin of Geography. Physical Geography 8: 47-57.

Forysiak J., 2012. Zapis zmian środowiska przyrodniczego późnego vistulianu i holocenu $\mathrm{w}$ osadach torfowisk regionu łódzkiego. Acta Geographica Lodziensia 99: 1-164.

Gawlik H., 1969. Wydmy w Kotlinie Szczercowskiej. W: R.Galon (red.), Procesy i formy wydmowe w Polsce, Prace Geograficzne, Instytut Geografii Polskiej Akademii Nauk 75: 249-287.

Gawlik H., 1970. Geomorfologia Kotliny Szczercowskiej. Acta Geographica Lodziensia 26: 1-104.

Gawlik J., 1994. Wpływ głębokiego i długotrwałego odwodnienia gleb hydrogenicznych na ich fizyczno-wodne właściwości, Wiadomości IMUZ 18(2): 11-77.

Gilewska S., 1999. Rzeźba. W: L.Starkel (red.), Geografia Polski. Środowisko przyrodnicze, Wydawnictwo Naukowe PWN, Warszawa: 244-288.

Goździk J., Zieliński T., 1996. Sedymentologia vistuliańskich osadów małych dolin środkowej Polski - przykłady z kopalni Bełchatów. Biuletyn Państwowego Instytutu Geologicznego 373: 67-77.

Jokiel P., Maksymiuk Z., 1988. Wpływ kopalni odkrywkowej “Bełchatów” na zmiany odpływu. W: I.Dynowska, (red.), Antropogeniczne uwarunkowania zmian odpływu i reżimu rzek w różnych regionach Polski. Dokumentacja Geograficzna 4: 79-94.

Kloss M., 2007. Roślinność subfosylna na tle historii wysokich torfowisk mszarnych w północno-wschodniej i środkowej Polsce oraz w Sudetach. Instytut Badawczy Leśnictwa, Sękocin Stary: 1-141. 
Kondracki J., 2009. Geografia regionalna Polski. Wydawnictwo PWN, Warszawa: 1-468.

Kucharski L., Pisarek W., 2001. Roślinność terenów podmokłych w Polsce Środkowej i jej ochrona. Chrońmy Przyrodę Ojczystą 57(5): 33-54.

Maksymiuk Z., 1985. Sieć hydrograficzna przed rozpoczęciem oraz we wstępnej fazie realizacji inwestycji bełchatowskiej. Zmiany w środowisku przyszłego Bełchatowskiego Okręgu Przemysłowego. Wydawnictwo Naukowe PWN, Warszawa-Łódź: 99-110.

Mamiński M., 1986. Zbiorowiska roślinne torfowisk Bełchatowskiego Okręgu Przemysłowego. Acta Universitatis Lodziensis, Folia Botanica 4: 85-137.

Manikowska B., 1996. Dwucykliczność ewolucji środowiska peryglacjalnego w Polsce środkowej podczas vistulianu. Biuletyn Państwowego Instytutu Geologicznego 373: 97-106.

Materac E., 2015. Morfologia i budowa geologiczna wybranych torfowisk w środkowym odcinku doliny Widawki. MS, Praca magisterska, Katedra Geomorfologii i Paleogeografii Uniwersytetu Łódzkiego: 1-47.

Myślińska E., 2006. Laboratoryjne badania gruntów. Wydawnictwo Naukowe PWN, Warszawa: 1-277.

Okupny D., Żurek S., Forysiak J., 2014. Analiza przestrzenna rozmieszczenia torfowisk regionu łódzkiego. Studia Limnologica et Telmatologica 8(2): 81-91.
Ralska-Jasiewiczowa M., Demske D., van Geel B., 1998. Late-Glacial vegetation history recorded in the Lake Gościąż sediments. W: M.Ralska-Jasiewiczowa, T.Goslar, T.Madeyska, L.Starkel (red.), Lake Gościąż, Central Poland. A monographic study. Part 1. Instytut Botaniki PAN Kraków: 128-143.

Tobolski K., 2000. Przewodnik do oznaczania torfów i osadów jeziornych. Wydawnictwo Naukowe PWN, Warszawa: 1-812.

Turkowska K., 1988. Rozwój dolin rzecznych na Wyżynie Łódzkiej w późnym czwartorzędzie. Acta Geographica Lodziensia, 57: 1-15.

Turkowska K., 2006. Geomorfologia Regionu Łódzkiego. Wydawnictwo Uniwersytetu Łódzkiego, Łódź: 1-237.

Twardy J., 2008. Transformacja rzeźby centralnej części Polski Środkowej w warunkach antropopresji. Wydawnictwo Uniwersytetu Łódzkiego, Łódź: 1-292.

Walanus A., Goslar T., 2009. Datowanie radiowęglowe. Wydawnictwa AGH, Kraków.

Wieczorek D., Stoiński A., 2013. Objaśnienia do Szczegółowej Mapy Geologicznej Polski w skali 1:50 000, ark. Szczerców (735). Centralne Archiwum Geologiczne, PIG-PIB, Warszawa.

Żurek S., 1987. Złoża torfowe Polski na tle stref torfowych Europy. Dokumentacja Geograficzna 4: 1-84. 